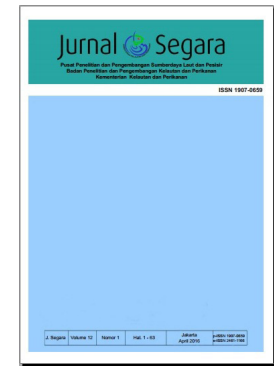

JURNAL SEGARA

http://ejournal-balitbang.kkp.go.id/index.php/segara

ISSN : 1907-0659

e-ISSN : 2461-1166

Nomor Akreditasi: 766/AU3/P2MI-LIPI/10/2016

\title{
ANALYSIS OF SALT PRODUCTION USING THE SALT LOCATION SUITABILITY INDEX TO APPLY THE CONTINUOUSLY DYNAMIC MIXING IN NORTH ACEH AND EAST ACEH
}

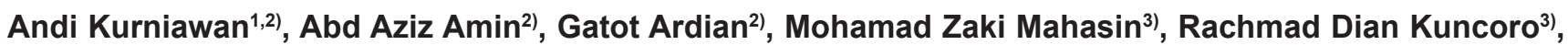 \\ Budiyanto $^{4)}$, Siti Mariya Ulfa ${ }^{5)}$, M. Amenan ${ }^{6)}$, Indah Yanti' ${ }^{5}$, \& Rika Kurniaty) \\ 1)Faculty of Fisheries and Marine Science, University of Brawijaya, Malang, Jawa Timur \\ ${ }^{2)}$ Coastal and Marine Research Centre, University of Brawijaya, Malang, Jawa Timur \\ ${ }^{3}$ Ministry of Marine Affairs and Fisheries of the Republic of Indonesia, Jakarta \\ ${ }^{4}$ BBajogkan Salt Farmers Group, Tuban, Jawa Timur \\ ${ }^{5)}$ Faculty of Mathematics and Natural Sciences, University of Brawijaya, Malang, Jawa Timur \\ ${ }^{6}$ Nahdlatu Ulama Islamic Institute of Tuban, Tuban, Jawa Timur \\ ${ }^{7)}$ Faculty of Law, University of Brawijaya, Malang, Jawa Timur
}

Received: 08 January 2020; Revised: 06 September 2021; Accepted: 16 September 2021

\begin{abstract}
One of the main potentials of marine resources in Indonesia is salt. Salt production locations are located in various regions of Indonesia. Aceh Province is one of the leading salt-producing areas on the island of Sumatra. Salt production in Aceh faces various challenges, such as the production system and salt production locations' suitability. Therefore, to develop salt production in Aceh, analysis of the production system and suitability of salt production sites are fundamental. This study aims to analyze the production system and the suitability of salt production locations in North Aceh Regency and East Aceh Regency as salt production centers in Aceh Province. This research uses a combination of qualitative and quantitative methods (mixed method) with a descriptive approach. Production system analysis is carried out through direct observation and in-depth interviews with the stakeholders (government and salt farmers). Analysis of the salt location's suitability level was carried out using the Salt Suitability Index (SSI) method. This study shows that the production system in North Aceh and East Aceh districts uses three production methods consisting of boiling seawater, solar evaporation, and a combination of boiling and solar evaporation. The main obstacle to salt production in Aceh is the weather, such as high rainfall and fluctuations throughout the year. Analysis of the suitability of the location of salt production shows the value of the SSI at the salt ponds site in the North Aceh and the East Aceh Regencies is $80 \%$ which indicates that the locations are sufficiently appropriate as a salt production site. The results of this study show that the application of the Continuously Dynamic Mixing (CDM) method in Greenhouse Salt Tunnel (GST) technology may be used to improve the quality and quantity of salt production in Aceh.
\end{abstract}

Keywords: Salt, salt suitability index, salt production, North Aceh, East Aceh.

Corresponding author:

Jl. Pasir Putih I Ancol Timur, Jakarta Utara 14430. Email: andi_k@ub.ac.id 


\section{INTRODUCTION}

Indonesia has a total sea area of $3.257 .357 \mathrm{~km}^{2}$ with coastal line of more than 81.000 line kmand therefore, marine resources are Indonesia's greatest potential. One of the main resources in the oceans is salt $(\mathrm{NaCl})$ (Kurniawan, 2018). With its regional characteristics, Indonesia is still not able to meet domestic salt needs, so it still needs to importing salt, especially for industry.

Salt is one of the most important commodities for the life of the Indonesian people. Sources of raw materials for salt may be obtained from sea water or brackish water (Kirabira et al., 2017). By definition, salt is a collection of compounds with the main content of $\mathrm{NaCl}(>80 \%)$ and contains elements of other compounds such as magnesium chloride, magnesium sulfate, and calcium chloride (Stan \& Fendhrian, 2011) Salt is widely used for consumption and industrial purposes (Kurniawan et al., 2019). Meanwhile, as an industrial raw material, salt is an important raw material for the industries of processed food, chemical or pharmaceutical, leather tanning and oil drilling (Rismana \& Nizar, 2014).

The main factors that affect salt production are the availability of seawater raw materials, weather conditions, and soil conditions from salt ponds. Salt production in Indonesia is mostly done by evaporating seawater which is channeled into salt ponds, so that weather conditions are one of the main determinants of the success of the salt production target. Evaporation of salt water could be achieved if it is supported by solar radiation and microclimate engineering assistance in salt areas, especially wind, rainfall, temperature, and humidity, as well as the duration of solar radiation (Kumala, 2012; Kurniawan et al., 2019). The intensity of rainfall and the distribution of rain in a year are indicators that closely related to the length of the dry season which affected the evaporation rate of seawater (Purbani, 2013).

One of the potential locations as a place of salt production in Indonesia is Aceh Province which is a representation of the salt production center area on Sumatra Island and represents the western region of Indonesia (Salim \& Munadi, 2016). Aceh is a cantilever zone for people's salt production, so that the target of the implementation of the People's Salt Business Empowerment (Pugar) program implemented by the Ministry of Maritime Affairs and Fisheries of the Republic of Indonesia. Although Aceh was an area that had a long and wide coastline, the salt production in this area was still dealing with many obstacles to meet the needs of consumption and industry properly. As a result, Aceh had to bring in salt from outside its territory to meet domestic needs. According to Razi et al. (2016)
Aceh imported an average of $6.581,3$ tons of salt/year.

Salt-producing areas in Aceh Province were North Aceh District and East Aceh District. North Aceh Regency, Aceh Province was an agricultural area and coastal or coastal areas/areas where most of the people made a living as farmers, fishermen, and salt farmers (Salim, 2010). North Aceh Regency was a potential area for the development of a salt-making business that could give jobs for the people who live in this area. Salt-producing areas in North Aceh consisted of Dewantara, Syamtalira Bayu, Lapang, and Seunuddon Districts (Rochwulaningsih, 2013). Meanwhile, East Aceh Regency had potential in the form of sea and land fisheries, ports, tourism, and industrial areas in coastal areas. Salt production in this district was also one of the businesses that had a great opportunity to provide jobs. However, salt production in North Aceh Regency and East Aceh Regency was still experiencing various obstacles, this was mainly due to rainfall which caused salt crystallization failure (Yusman, 2019)

To be able to develop salt production in Aceh, it was necessary to analyze the salt production system and the suitability of the salt pond location. This study aimed to analyze the existing salt production system in North Aceh Regency and East Aceh Regency as part of the salt production center in Aceh. In addition, this study analyzed the level of suitability of salt production locations in the districts of North Aceh and East Aceh based on the assessment of the Salt Location Suitability Index (SSI) (Kurniawan et al., 2019). The SSI was based on nine parameters that determine the salt production process, namely rainfall, soil permeability, soil type, irradiation time, humidity, wind speed, air temperature, evaporation rate, and water saturation level of salt raw materials (Kurniawan et al., 2019). Based on the results of this study, the application of the Continuously Dynamic Mixing (CDM) method in Greenhouse Salt Tunnel (GST) technology could be a solution to improve the quality and quantity of salt production in Aceh. The Continuously Dynamic Mixing (CDM) method was a special method used in the Greenhouse Salt Tunnel (GST) crystallization house technology which was developed to increase salt production throughout the year which was not affected by the rainy season by adjusting water mixing and displacement to increase the Baumé water scale value, so that throughout year the salt production could still be done (Kurniawan et al., 2019). The basic principle of the Continuously Dynamic Mixing (CDM) method was to carry out water mixing and transference processes continuously and dynamically to ensure that the water aging process was continued and the volume of water was sufficient to be raised on the crystallization table. 


\section{METHODOLOGY}

\section{Research Sites}

This research was conducted by observing salt production locations and analyzing the SSI values of salt production locations in North Aceh District (Syamtalira Bayu District) and East Aceh District (Peureulak District). The map of this research location was shown in Figure 1. The selection of research sites was based on the potential of ponds and the target for integration of salt production areas set by the Ministry of Maritime Affairs and Fisheries of the Republic of Indonesia.

\section{Research Approach}

This study used a combination of qualitative and quantitative methods (mixed method) with a descriptive approach. Production system analysis was carried out through direct observation combined with deep interviews with salt production stakeholders (government and salt business actors). The analysis of the suitability level of salt locations was carried out using the Salt Production Location Suitability Index (SSI) method (Kurniawan et al., 2019).

\section{Tools and Materials}

The tools used in this observation were polyethylene (PP) plastic bags, cameras and stationery. Air temperature was measured using a Digital Thermometer (HTC-2). Wind speed was measured using a Digital Anemometer (GM8902, Benetech). Evaporation rate was estimated from the decrease in water level (cm/day). Humidity was measured using a Digital Hygrometer (HTC-2). The level of water saturation (Baumé Scale) was measured with a Boumehydrometer (Alla france, 0-30).

\section{Data Analysis}

The variables in this study involved the parameters in the Salt Location Suitability Index (SSI) in Table 1 which included: rainfall $(\mathrm{mm})$, soil type, soil permeability $(\mathrm{k})$, irradiation time (hours/day), humidity (\%), speed wind $(\mathrm{m} / \mathrm{s})$, air temperature $\left({ }^{\circ} \mathrm{C}\right)$, evaporation rate $(\mathrm{mm} /$ day), and raw material water saturation level $\left({ }^{\circ} \mathrm{Be}\right)$ (Table 1).

The analysis of site suitability for salt production was carried out using quantitative analysis to facilitate drawing conclusions based on the assessment of of the suitability of the location of salt production Index (SSI) (Kurniawan et al., 2019). The SSI calculation was based on the results of the assessment of the level of suitability of the variables on the SSI parameters. The suitability of the salt production location was calculated using the formula for assessing the suitability class for salt pond locations in North Aceh Regency and East Aceh Regency as followed in Equal 1.

$I K G=(\Sigma \mathrm{Ni} / \mathrm{Nmaks}) \times 100 \%$ 1)

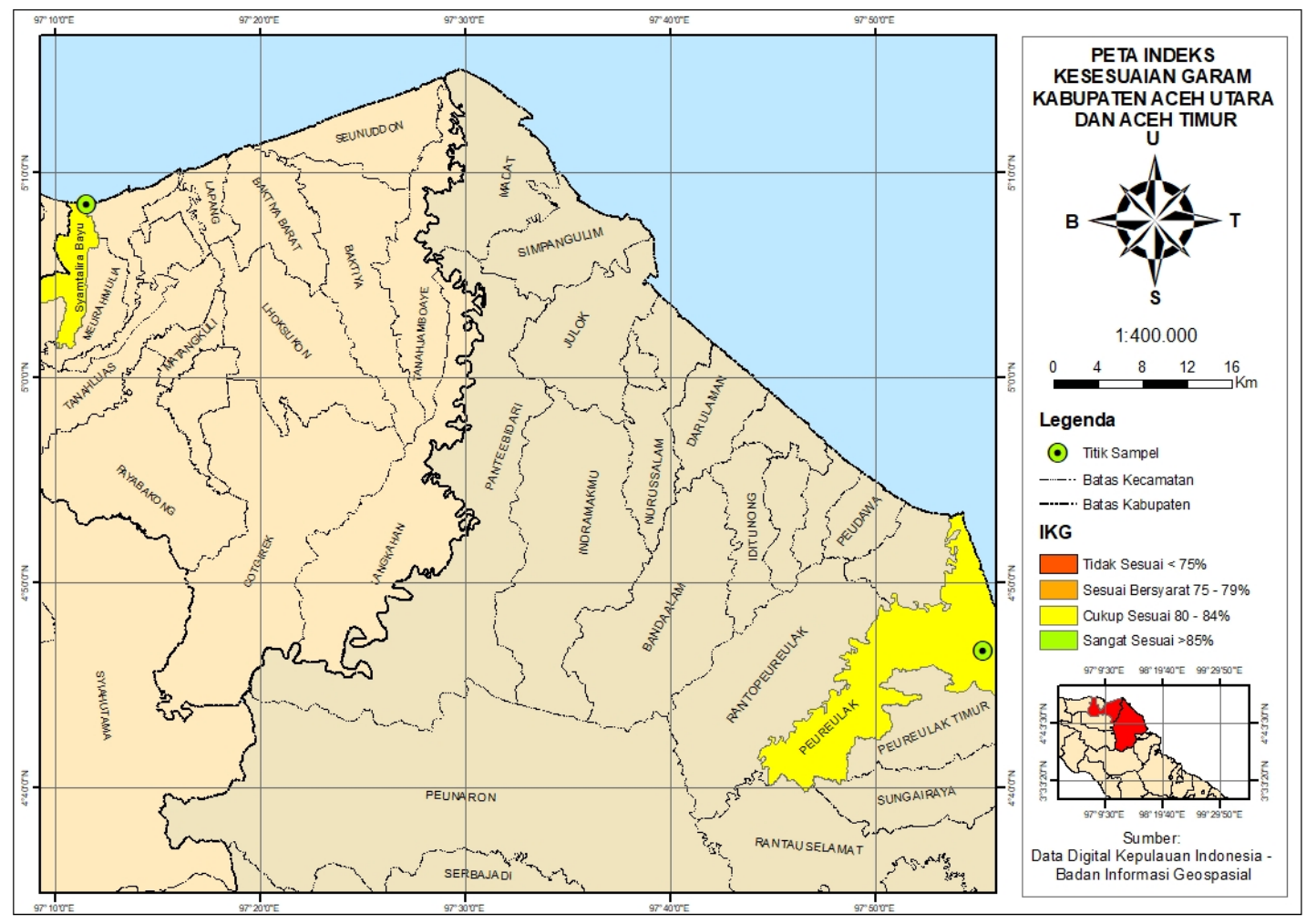

Figure 1. Map of North Aceh and East Aceh Salt Conformity Index Results. 
Table 1.

Parameter Value of Salt Location Suitability Index (SSI) (Kurniawan et al., 2019)

\begin{tabular}{|c|c|c|c|c|c|c|c|c|c|}
\hline \multirow[t]{2}{*}{ Paramater } & \multirow[t]{2}{*}{ Quality } & \multicolumn{2}{|c|}{ S1 Category } & \multicolumn{2}{|c|}{ S2 Category } & \multicolumn{2}{|c|}{ S3 Category } & \multicolumn{2}{|c|}{ N Category } \\
\hline & & Value & Score & Value & Score & Value & Score & Value & Score \\
\hline Rainfall (mm) & 5 & $<10$ & 4 & $10-100$ & 3 & $100-200$ & 2 & $>200$ & 1 \\
\hline Soil permeability (k) & 5 & $1 \times 10^{-4}$ & 4 & $<1 \times 10^{-3}$ & 3 & $<1 \times 10^{-2}$ & 2 & $<1 \times 10^{-1}$ & 1 \\
\hline Type of soil & 5 & Clay & 4 & $\begin{array}{l}\text { Sandy } \\
\text { Clay }\end{array}$ & 3 & Loam & 2 & Silty & 1 \\
\hline $\begin{array}{l}\text { Exposure Time } \\
\text { (hours/day) }\end{array}$ & 5 & $>8,7$ & 4 & $5,5-8,6$ & 3 & $2,3-5,4$ & 2 & $<2,3$ & 1 \\
\hline Humidity (\%) & 5 & $<45-59$ & 4 & $60-74$ & 3 & $75-90$ & 2 & $>90$ & 1 \\
\hline Wind speed $(\mathrm{m} / \mathrm{s})$ & 5 & $>5.7$ & 4 & $4.1-5.7$ & 3 & $2,4-4,0$ & 2 & $<2,4$ & 1 \\
\hline Air temperature $\left({ }^{\circ} \mathrm{C}\right)$ & 5 & $>32$ & 4 & $28.5-32$ & 3 & $25-28,4$ & 2 & $<25$ & 1 \\
\hline Evaporation (mm/day) & 5 & $>2.0$ & 4 & $1.5-2.0$ & 3 & $1,0-1,4$ & 2 & $<1,0$ & 1 \\
\hline Water saturation $\left({ }^{\circ} \mathrm{Be}\right)$ & 5 & $\geq 2$ & 4 & $1.5-1.9$ & 3 & $1.0-1.5$ & 2 & $<1$ & 1 \\
\hline
\end{tabular}

Description: S1: Very Suitable; S2: Fairly Suitable ; S3: Conditionally Fit; N: Not Suitable

Where SSI was the Index of Suitability of Salt Production Locations, Ni was the i-th Parameter Value (weight $\times$ score) and Nmax was the Maximum Value of a category. Meanwhile, the determination of the suitability criteria as a location for salt production was based on the SSI score as follows:

$\cdot>85 \%=$ Very suitable (S1)
$\cdot 80-84 \%=$ Quite suitable (S2)
$\cdot 75-79 \%=$ Conditionally (S3)
$\cdot<75 \%=$ Not suitable (N)

\section{RESULTS AND DISCUSSION}

\section{Salt Production Method Analysis}

Salt production in North Aceh District and East Aceh District was carried out by several production methods. The main production methods used are boiling, solar evaporation, and a combination of evaporation and boiling.

The method of producing salt by boiling was

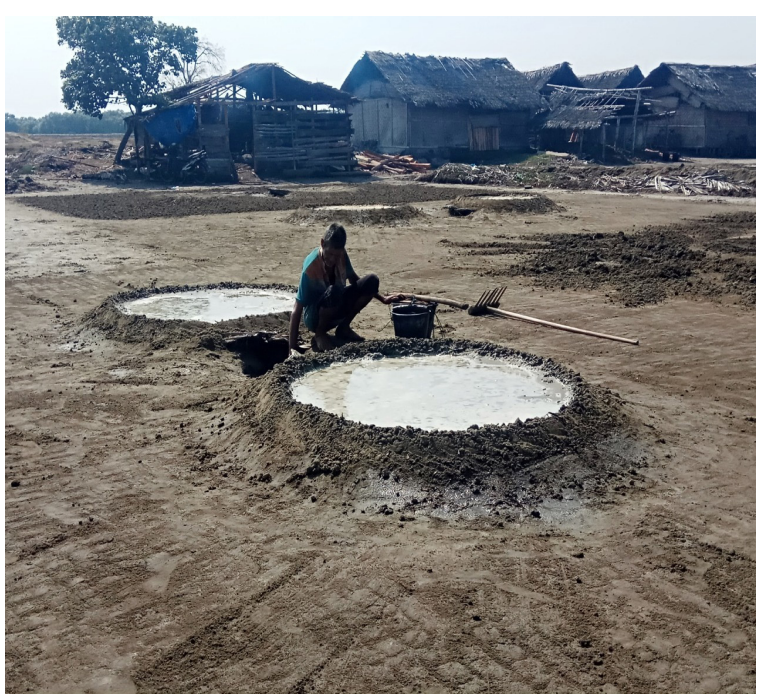

carried out using sea water as the raw material for salt (Figure 2). Seawater was boiled by using a flame as a source of heat energy to produce salt directly without going through the evaporation process with the help of sunlight. The resulting salt crystals were finely textured. The obstacles faced through this boiling production system were limited raw materials, availability of equipment, low production capacity, and the relatively difficult process of moving raw materials. In addition, the quality of the salt produced was still low $(\mathrm{NaCl}<$ $90 \%$ ). The low $\mathrm{NaCl}$ content was very possible because the direct crystallization process from sea water was carried out.

The production method by the solar evaporation was a salt production system which was generally carried out by salt farmers in Indonesia, namely by evaporating seawater into old water that ready to be crystallized in open fields by utilizing sunlight. Old water is a term used for water with a high density after going through the evaporation process. This old water will be crystallized to become salt $(\mathrm{NaCl})$. In the production

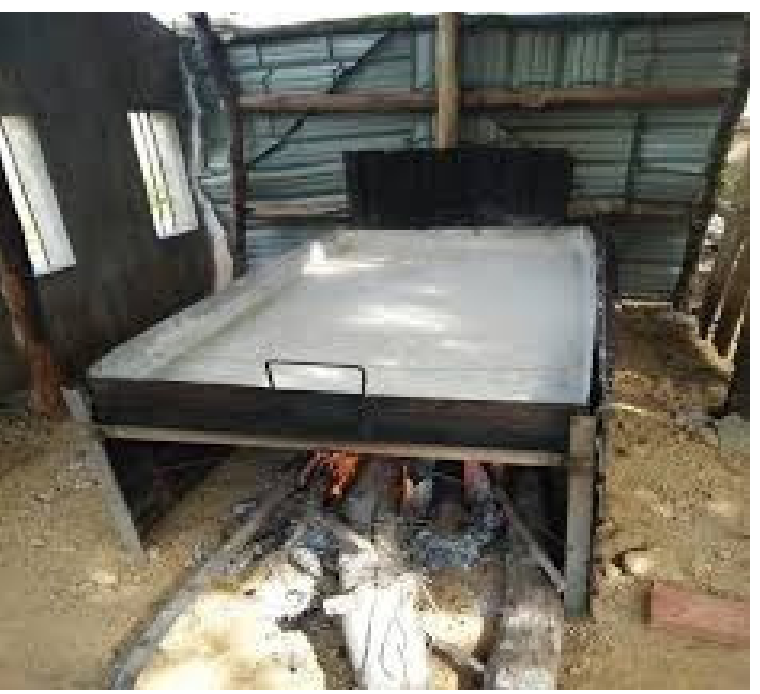

Figure 2. $\quad$ Production methods for collecting salt water (a) and boiling old water (b) in Aceh. 
system with solar evaporation, the salt production process was carried out through the purification stage (making old water) and the salt crystallization stage. The production capacity of this system could be higher than that of the boiling system, but it was greatly affected by climatic conditions, especially rainfall. When it rained the old water that has been produced can return to young water, forcing the production process to be done from the beginning again. The production system with solar evaporation would also stop during the rainy season.

The combined production process between evaporation and boiling was basically a modification of the salt production system with a combination of boiling and solar evaporation production systems. This system was done by combining the evaporation process with the help of sunlight to get old water which was then boiled to produce salt crystals. The evaporation process to produce old water was carried out in open fields. The old water produced was transferred to a boiling device and then boiled with the help of a flame to produce salt crystals.

Salt production data from the Ministry of Maritime Affairs and Fisheries of the Republic of Indonesia in 2019 shows that the average productivity of salt production in Aceh is about 38 tons/ha/year. The productivity of salt production in Central Java is about 54 tons/ha/year, while East Java is about 59 tons/ha/ year. Salt production innovation is needed to increase these productivities. Salt productivity in Indonesia varies from year to year, depending on weather conditions. In general, the productivity of salt fields in Indonesia is 50-100 tons/ha/year.

\section{The Analysis of Suitability of Salt Production Locations}

The assessment of the suitability of production sites in East Aceh Regency and North Aceh Regency as salt production areas was carried out using the suitability of the location of salt production Index (SSI). SSI was a method for analyzing the location of salt based on nine parameters as described by Kurniawan et al. (2019). The description of the results of the analysis of the SSI variables in the districts of East and North Aceh was as followed:

\section{Rainfall}

The analysis of site suitability for salt production based on rainfall conditions was carried out by analyzing the average annuall rainfall (Figure 3). Climatological observation data from the Malik Al-Shaleh BMKG observation station showed that the average rainfall in 2019 in North Aceh and East Aceh districts is around $20 \mathrm{~mm} / \mathrm{month}$. The annual rainfall data in the districts of East Aceh and North Aceh showed that these two areas have fluctuating rainfall intensity throughout the year.

Data from the Climatology and Geophysics Agency for Malik Al Salih station in 2018 showed that rain continues to occur frequently in the Aceh Province during the dry season, especially in April and September. Even the existing rainfall could reach the range of $50 \mathrm{~mm} / \mathrm{month}$. According to the Central

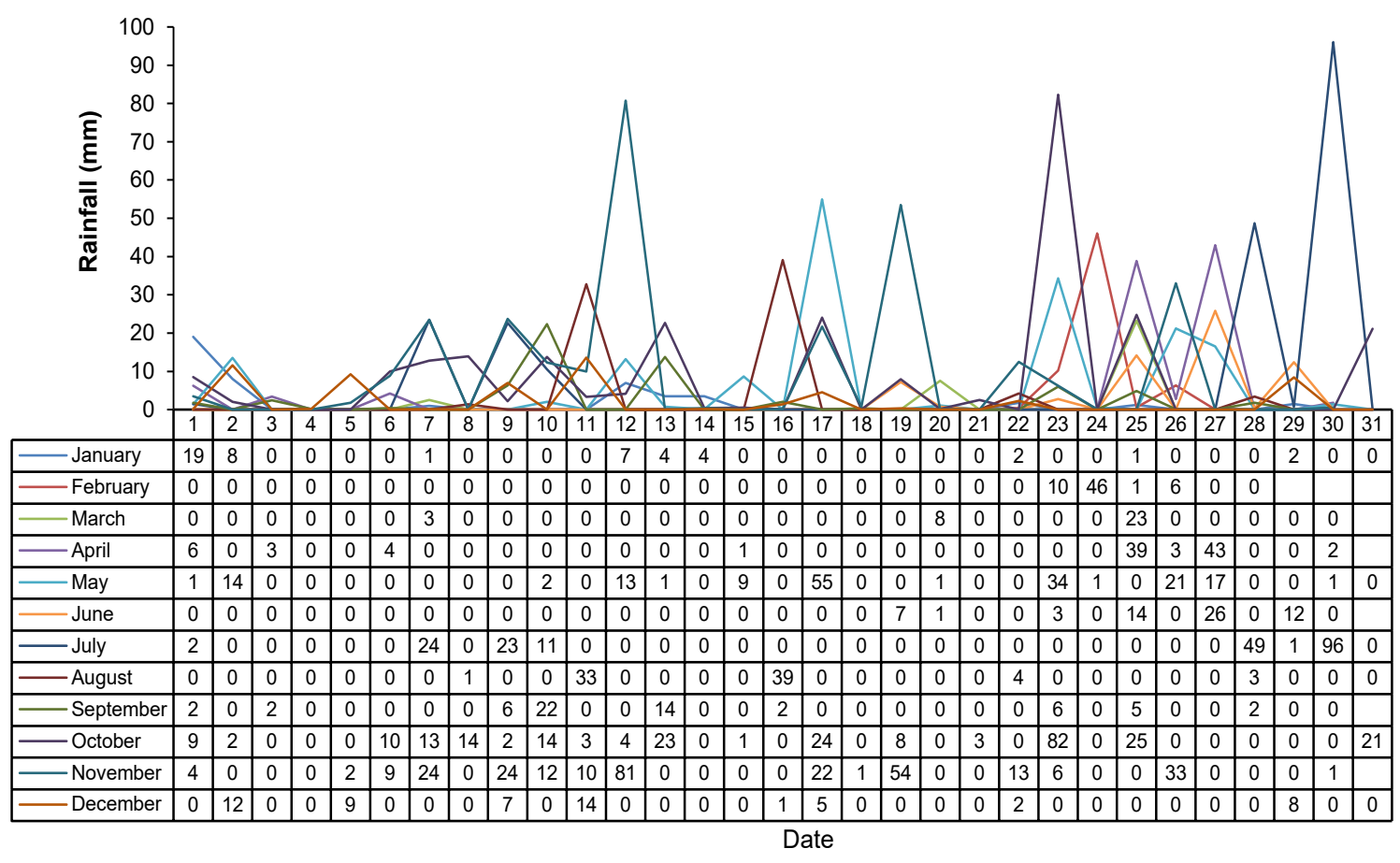

Figure 3. Daily Rainfall in North Aceh and East Aceh Districts in 2018 (source: BMKG Data). 
Statistics Agency (BPS) of Aceh Province (2016), it rained almost all year round in the Aceh region. Rainfall itself was one of the determinants of the success of the salt production target (Kurniawan et al., 2019; Zuhud, 2014). The average rainfall intensity and rainfall pattern in a year were indicators that are closely related to the length of time irradiating the sun. The length of this irradiation would affect the rate of evaporation of water at the salt production site. High levels of rainfall would have a negative impact on salt production (Jaziri et al., 2018; Purbani, 2006).

The results of this assessment indicated that the SSI value for rainfall in the two locations had a class S2 category (quite appropriate). However, rainfall that fluctuates throughout the year tended to direct the SSI value of rainfall in this area to S3 (Conditionally). Fluctuating rainfall conditions required solutions in the form of technological innovations that made the saltmaking process more resistant to rainfall disturbances.

\section{Soil Permeability}

Soil permeability measurements were carried out for each salt production site in North Aceh District (Syamtalira Bayu District) and East Aceh District (Peureulak District). Soil permeability was one of the criteria for suitability in salt pond locations (Kutlek et al., 2006). Soil permeability itself was related to the level of soil porosity which also affected the success of salt production (Wairu et al., 2006).

The permeability value of salt pond soil in North Aceh Regency was $1 \times 10^{-4}(\mathrm{k})$, while the soil permeability value in East Aceh Regency was 1×10-4 (k). The value of soil permeability in North Aceh District was lower than East Aceh District. The results of the SSI analysis for soil permeability indicated that the location of salt ponds in North Aceh Regency and East Aceh Regency was included in the S1 category (Very suitable) for salt production.

\section{Type of soil}

The soil type was largely determined by the amount of sand, silt, and clay composition. The type of soil selected for the pond should be impermeable (not porous) which meant the soil should have low permeability (Hanafiah, 2007). This permeability was determined from the existing soil pore system. Soil pore system was strongly influenced by the soil type (Chun et al., 2008).

Observation of soil type at salt pond locations in East Aceh Regency and North Aceh Regency showed that the soil type in salt ponds in both locations was clay soil type, so that the SSI value for soil type at both locations was categorized as S1 (Very suitable). Clay soil type (clay) was very good and suitable for ponds such as salt ponds because such soil was very hard and would crack in dried, while in wet conditions it had a good ability to hold water (Ghufran, 2011).

\section{Exposure Time}

The observation of the duration of the irradiation was carried out using data from the BMKG online data center. The results of the observations showed that the average irradiation time in both research locations was 7.8 hours/day. It showed that the length of irradiation in the districts of North and East Aceh was included in the S2 category in assessing the suitability of the salt production location with an SSI value of 15. Ruskowitz et al. (2014) reported that the length of irradiation at the salt production site greatly affected the evaporation rate and could increase the brine saturation value.

Water evaporation could be achieved properly if it was supported by solar radiation and microclimate engineering assistance in salt areas (Kumala, 2012). The duration of sunshine was one of the important indicators in climatology. Sunlight would drive photochemical reactions in the atmosphere including the formation of water vapor (Dong et al., 2021).

\section{Air Humidity}

The air humidity greatly affected the evaporation process which was important in the process of making salt (Ruskowitz et al., 2014). If the humidity was high, the evaporation rate would be low because the air saturation will be achieved faster. Air humidity affected the rate of evaporation of water, where the greater the evaporation was, the greater the amount of salt crystals that settled (Dong et al., 2021).

The results of the analysis in this study indicated that the humidity in North Aceh and East Aceh districts was around $60 \%$. Based on the SSI assessment, the humidity condition had a value of 15 and was included in the S2 (Sufficiently Appropriate) category.

\section{Wind Speed}

Wind speed was very influential in determining the location of salt ponds because it would affect the speed of water evaporation. Where the greater the evaporation was, the greater the number of salt crystals that settled (Ruskowitz et al., 2014). Purbani (2003) stated that the supporting factors as a requirement for making salt were climatological components such as rainfall, number of rainy days and wind speed.

Wind speed measurements showed that the average wind speed in North Aceh and East Aceh districts was $1.7 \mathrm{~m} / \mathrm{second}$. The results of the SSI analysis at both locations showed that the SSI value for wind speed in both locations was 5 . This condition was included in the $\mathrm{N}$ category (not suitable). The ideal wind speed for salt production was $4.5-5.0 \mathrm{~m} / \mathrm{s}$ (Azizi et al., 2011). This condition showed that a technological 
approach was needed that could engineer wind speed to support salt production in both locations.

\section{Air temperature}

The air temperature greatly affected the rate of evaporation of water. Where the greater the evaporation was, the greater the number of salt crystals formed (Dong et al., 2021). Air temperature conditions were one of the main environmental factors that would determine the success of salt production. Therefore, in determining the suitability of the salt location, the most important air temperature measurement was during the day.

The results of measurement showed that the average air temperature during the day at the salt production sites in North Aceh Regency and East Aceh Regency was around $32{ }^{\circ} \mathrm{C}$. Based on the SSI analysis, this air temperature was included in the $\mathrm{S} 1$ (Very Appropriate) category. These results indicated that from the air temperature level factor, the location of salt ponds in North Aceh Regency and East Aceh Regency was very suitable to support the salt production process.

\section{Evaporation Rate}

The observation of the evaporation rate was carried out by estimating the daily rate of evaporation in salt ponds at the study site. The factors that most determine the rate of evaporation of water in the process of making salt were wind speed and solar radiation. The wind speed had an effect because the wind carried water vapor from the surface of the water so that the evaporation process could take place. Solar radiation had an effect because it was a source of energy for the evaporation process (Santosa, 2014).

The method used to predict the evaporation rate in this research was using Blaney-Criddle method (1950), while the calculation of the evaporation rate was followed:

$\mathrm{ETo}=p(0.46 \mathrm{~T}+8)$

Where $\mathrm{T}$ was the average daily temperature $\left({ }^{\circ} \mathrm{C}\right)$, $\mathrm{p}$ was the average daily percentage of annual daylight hours $(5 \%)$, and ETo was the potential evapotranspiration ( $\mathrm{mm} /$ day).

From these results, the average daily temperature value was $27^{\circ} \mathrm{C}$ and the average percentage of annual daytime evaporation was 0.15 , so that the potential evaotranspiration at the study site was $3.2 \mathrm{~mm} /$ day. This evaporation rate was included in the $\mathbf{S 1}$ (Very Suitable) category. It showed that the value of water evaporation, despite the high wind speed and rainfall in the districts of North Aceh and East Aceh, could still run well so that it could be used for the salt production process.

\section{Raw Material Water Saturation}

The process of forming salt crystals was influenced by many factors, including the level of water saturation of the salt raw material. This level of saturation would determine how long it produced the salt. The level of water saturation was an indicator of how much mineral salts were contained in seawater where the main mineral salt was $\mathrm{NaCl}$. The level of saturation of the raw salt water in this study was analyzed based on the degree of the Baumé Scale $\left({ }^{\circ} \mathrm{Be}\right.$ ) (Kurniawan, et al, 2019). Observation of raw material saturation was carried out at the salt pond location.

Sampling of water as raw material for salt production was carried out at the location of the salt pond, Syamtalira Bayu District, North Aceh Regency and Peureulak District, East Aceh Regency. The results showed that the level of water saturation of the raw material for salt production in both locations was $3^{\circ} \mathrm{Be}$. This level of saturation based on the SSI analysis was included in the $\mathbf{S 1}$ category (Very Suitable). The existence of the production of raw materials was the beginning of the success of the salt production business. If the availability of raw material water at a location met production needs, it could be said that the location had the potential to become a salt production area (Kurniawan et al., 2019; Sandy et al., 2017).

\section{The Assessment of Salt Location Suitability Index (SSI)}

Based on the results of the analysis of all SSI variables at salt pond locations in North Aceh and East Aceh districts, the total SSI value was analyzed for each of these locations. The SSI analysis in North Aceh Regency showed that this location had a Conformity Index value of $80 \%$ which indicated that the salt location in North Aceh Regency was included in the S2 category or is quite suitable to be used as a salt pond location (Table 2). The results of the analysis in this study showed that the SSI value in East Aceh Regency also had a salt suitability index value of $80 \%$ (Sufficiently Suitable)(Table 3). These results indicated that the two locations in this study were quite suitable as a place to develop salt production. However, it was necessary to apply salt production technology to overcome the main challenges in salt production that were faced to optimize the existing salt production.

The salt production process in Aceh Utara and Aceh Timur districts was challenged by climate conditions in Aceh, such as the level of rainfall. Aceh was an area with high rainfall intensity where it rains every month. Another factor that needed attention was the condition of the daily wind speed which tended to be slow. Therefore, a Standard Operating Procedure (SOP) was needed by applying technology that could overcome these two environmental factors so as to optimize salt production in Aceh. 
Table 2. Parameter Value of Salt Location Suitability Index (SSI) (Kurniawan et al., 2019)

\begin{tabular}{|c|c|c|c|c|c|c|}
\hline No & Paramater & $\begin{array}{l}\text { Measurement } \\
\text { results }\end{array}$ & Category & Quality & Score & $\mathbf{N i}=\mathbf{B} \times \mathbf{S}$ \\
\hline 1 & Rainfall (mm) & 20 & $\mathrm{~S} 2$ & 5 & 3 & 15 \\
\hline 2 & Soil permeability (k) & $1 \times 10^{-4}$ & $\mathrm{~S} 1$ & 5 & 4 & 20 \\
\hline 3 & Type of soil & Clay & $\mathrm{S} 1$ & 5 & 4 & 20 \\
\hline 4 & Exposure time (hours) & 7,8 & $\mathrm{~S} 2$ & 5 & 3 & 15 \\
\hline 5 & Humidity (\%) & 60 & $\mathrm{~S} 2$ & 5 & 3 & 15 \\
\hline 6 & Wind speed (m/s) & 1,7 & $\mathrm{~N}$ & 5 & 1 & 5 \\
\hline 7 & Air temperature $\left({ }^{\circ} \mathrm{C}\right)$ & 32 & $\mathrm{~S} 2$ & 5 & 3 & 15 \\
\hline 8 & Evaporation (mm/day) & 3,2 & $\mathrm{~S} 1$ & 5 & 4 & 20 \\
\hline 9 & $\begin{array}{l}\text { Raw material water } \\
\text { saturation }\left({ }^{\circ} \mathrm{Be}\right)\end{array}$ & 3 & S1 & 5 & 4 & 20 \\
\hline
\end{tabular}

Table 3. Parameters of SSI Locations in Peureulak District, East Aceh Regency

\begin{tabular}{|c|c|c|c|c|c|c|}
\hline No & Paramater & $\begin{array}{l}\text { Measurement } \\
\text { results }\end{array}$ & Category & Quality & Score & $\mathbf{N i}=\mathbf{B} \times \mathbf{S}$ \\
\hline 1 & Rainfall (mm) & 20 & $\mathrm{~S} 2$ & 5 & 3 & 15 \\
\hline 2 & Soil permeability (k) & $1 \times 10^{-4}$ & $\mathrm{~S} 1$ & 5 & 4 & 20 \\
\hline 3 & Type of soil & Clay & $\mathrm{S} 1$ & 5 & 4 & 20 \\
\hline 4 & Exposure time (hours) & 7,8 & $\mathrm{~S} 2$ & 5 & 3 & 15 \\
\hline 5 & Humidity $(\%)$ & 60 & $\mathrm{~S} 2$ & 5 & 3 & 15 \\
\hline 6 & Wind speed (m/s) & 1,7 & $\mathrm{~N}$ & 5 & 1 & 5 \\
\hline 7 & Air temperature $\left({ }^{\circ} \mathrm{C}\right)$ & 32 & $\mathrm{~S} 2$ & 5 & 3 & 15 \\
\hline 8 & Evaporation (mm/day) & 3,2 & $\mathrm{~S} 1$ & 5 & 4 & 20 \\
\hline 9 & $\begin{array}{l}\text { Raw material water } \\
\text { saturation }\left({ }^{\circ} \mathrm{Be}\right)\end{array}$ & 3 & $\mathrm{~S} 1$ & 5 & 4 & 20 \\
\hline
\end{tabular}

The SSI value in this study indicated that the location of salt ponds in the Aceh region, especially North Aceh and East Aceh, was suitable for the salt production process, but it had a conditional category in salt production on the variables of rainfall and wind speed. This requirement could be met by applying the Continuously Dynamic Mixing (CDM) method with Greenhouse Salt Tunnel technology (Kurniawan et al., 2019). The Continuous Dynamic Mixing (CDM) method and Greenhouse Salt Tunnel (GST) technology in the production of salt were basically salt production methods by mixing water with different Baumé scale levels to accelerate the evaporation rate. The evaporation optimization was done by building an evaporation house construction in the form of a Greenhouse Salt Tunnel (GST) tunnel. Because evaporation was carried out in the Greenhouse Salt Tunnel (GST) construction, the evaporation process could still be carried out when it rained even in the rainy season. The application of the Continuously Dynamic Mixing (CDM) method in the Greenhouse Salt Tunnel (GST), made salt production more resistant to fluctuating weather even during the rainy season. Existing tunnel construction could also be used to accelerate the wind speed thereby accelerating evaporation. A synergistic approach to salt production in the rainy season and dry season based on the development of the Continuously Dynamic
Mixing (CDM) method in GST technology made salt harvesting possible all year round. With the 14 Greenhouse Salt Tunnel (GST) approach, in 1 hectare of land, the salt production that could be obtained in the rainy season was \pm 14.4 tons/Ha, and in the dry season was \pm 150 tons $/ \mathrm{Ha}$. The estimated salt harvest using the Greenhouse Salt Tunnel (GST) technology and the Continuously Dynamic Mixing (CDM) method with the production strategy approach developed in this study was \pm 164.4 tons/ha/year (Kurniawan et al., 2019).

The application of technological innovation required a sufficient level of user knowledge and support from policy makers in development. The application of the CDM method in GST should be accompanied by guidelines in the form of Standard Operating Procedures (SOP). This SOP could not only be applied in North Aceh and East Aceh districts but also in areas with similar climatic conditions. To ensure this SOP runs, a mentoring program was needed, especially by the government as a policy maker in development. The mentoring process itself would be able to run well if the existing mentoring personnel are equipped with adequate mastery of the application of technology. This control could be carried out through the salt production competency certification process as part of the Salt Production (SKKNI). 
Modification of the CDM method in GST was absolutely necessary for the application of this technological innovation in North Aceh and East Aceh districts. Alternative modifications included making a special GST construction for young water and old water bunkers so that the water produced in the salt production process (increased the level of saturation) could be maintained at its saturation level when it rains. The CDM method in GST could also be used to make the salt production process in the Aceh region possible throughout the year (Kurniawan et al., 2019).

\section{CONCLUSION}

The production system in North Aceh Regency and East Aceh Regency used three production systems consisting of the boiling method of sea water, the method of evaporation (Solar evaporation), and the combined method of boiling and solar evaporation. The main obstacle to salt production in Aceh was the high and fluctuating rainfall throughout the year which results in suboptimal salt production and the wind speed tends to be slow. The SSI analysis showed that salt production locations in North Aceh and East Aceh districts were quite suitable as salt production locations $(80 \%$ SSI value). These results indicated that salt production in both locations could be optimized by applying the right technology. The main concerns in developing salt production in North Aceh and East Aceh districts were rainfall and wind speed conditions. The results of this study indicated that the application of the Continuously Dynamic Mixing (CDM) method in Greenhouse Salt Tunnel (GST) technology could be used to improve the quality and quantity of salt production in North Aceh and East Aceh districts. Recommendations for optimizing the program to increase salt production in North Aceh and East Aceh districts based on research results were:

- Preparation of Standard Operating Procedures (SOP) for special salt production for the Aceh region and areas with the same climate and weather conditions based on the Continuous Dynamix Mixing method.

- Construction of water reservoirs (bunkers for old and young water) in the cleaning phase based on the construction of the Greenhouse Salt Tunnel.

- The use of the Greenhouse Salt Tunnel as a crystallization table in the dry season and as a unitary production unit in the rainy season where the phase of purification until crystallization was carried out completely in the Greenhouse Salt Tunnel.

- Assistance in the salt production process through certified assistants with competency standards that were part of the SKKNI for Salt Production.

\section{ACKOWLEDGEMENTS}

This research is supported by the Leading Development Research Grant (HAPPU) University of
Brawijaya. The authors would like to thank the Ministry of Marine and Fisheries and all parties who have assisted in the implementation of this research. The main author of this article is Andi Kurniawan.

\section{REFFERENCE}

Azizi, A., Kurnawan, T., \& Manadiyanto. (2011, in Indonesian). Marketing Analysis of People's Salt in Pati Regency, Central Java. In Seminar Nasional Riset dan Kebijakan Sosial Ekonomi Kelautan dan Perikanan Tahun 2011 (pp. 541552). Jakarta, Indonesia: Kementerian Perikanan dan Kelautan Republik Indonesia.

BPS ACEH. (2016, in Indonesian). Aceh Development Profile 2016.

Chun, H.C., Giménez, D., \& Yoon, S.W. (2008). Morphology, Lacunarity and Entropy of IntraAggregate Pores: Aggregate Size and Soil Management Effects. Geoderma, 146(1), 83-93.

Dong, L., Xiong, Y., Huang, Q., Xu, X., Huo, Z., \& Huang, G. (2021). Evaporation-Induced Salt Crystallization and Feedback on Hydrological Functions in Porous Media with Different Grain Morphologies. Journal of Hydrology, 598,126427.

Hanafiah, K.A. (2007, in Indonesian). Soil Science Fundamentals. Raja Grafindo Persada: Jakarta.

Jaziri, A.A., Setiawan, W., Prihanto, A., \& Kurniawan A. (2018). Preliminary Design of a Lowcost Greenhouse for Salt Production in Indonesia. IOP Conference Series Earth and Environmental Science 137(1), 012054. Malang, Indonesia: Asean-FEN International Fisheries Symposium, Brawijaya University.

Kirabira, J.B., Kasedde, H., \& Lwanyaga, D. (2017). Optimization of Process Parameters in The Batch Crystallization of Sodium Chloride from Brine by The Taguchi Method. Int. J. Sci. Technol. Res, 6, 160-165.

Kumala, A. (2012, in Indonesian). Analysis of the Effect of Rainfall on Salt Productivity (Case Study: Pegaraman I Sumenep, PT. Garam (Persero)). Skripsi. Institut Pertanian Bogor: Bogor.

Kurniawan, A., Jaziri, A.A., Amin, A.A., \& Salamah, L. N. (2019, in Indonesian). Salt Suitability Index to Determine the Suitability of Salt Production Locations; Analysis of Salt Production Locations in Tuban and Probolinggo Regencies. J. Fisheries and Marine Research, 3(2), 236-244. 
Kurniawan, A., Syafii, M.I., Ardian, G., \& Jaziri, A.A. (2019). Continuously Dynamic Mixing (CDM) Method and Greenhouse Salt Tunnel (GST) Technology for Sea Salt Production throughout the Year. J. Ilmu Perikanan dan Kelautan, 11(2), 82-91.

Kurniawan, A. (2018, in Indonesian). Aquatic System Ecology: Fundamentals in the Utilization and Conservation of the Aquatic Environment (p. 173). Malang: Universitas Brawijaya Press.

Kutílek, M., Jendele, L., \& Panayiotopoulos. K.P. (2006). The Influence of Uniaxial Compression Upon Pore Size Distribution in Bi-Modal Soils. Soil Tillage Res, 86(1), 27-37.

PT. Garam. (2000, in Indonesian). Production Technology and Constraints to Salt Production in Indonesia. Kementrian Kelautan dan Perikanan: Jakarta.

Purbani, D. (2006, in Indonesian). Salt Crystallization Formation Process. Pus. Ris. Wil. Laut dan Sumberd. Nonhayati, Departemen Kelautan dan Perikanan Indonesia: Jakarta.

Razi, F., Ismayani., \& Iskandar, E. (2016, in Indonesian). Analysis of Developments and Factors Affecting the Import of Salt in Aceh Province. Jurnal IImiah Mahasiswa Pertanian Unsyiah. 1(1), 346-352.

Rismana, E., \& Nizar. (2014, in Indonesian). Study of Salt Production Process for Various Foods. Chemistry Progress, 7(1), 25-28.

Rochwulaningsih, Y. (2013, in Indonesian). SocioCultural Study of Salt Business in Aceh. Humanika. 18(2).

Ruskowitz, J.A., Suárez, F., Tyler, S.W., \& Childress, A.E. (2014). Evaporation Suppression and Solar Energy Collection in a Salt-Gradient Solar Pond. Solar Energy, 99, 36-46.

Salim, M. (2010, in Indonesian). Dynamics of Maritime Affairs and Fisheries Policy in Rembang Regency during the Reformation and Regional Autonomy Period 1998-2008. Universitas Diponegoro.

Salim., Zamroni., \& Ernawati, M. (2016, in Indonesian). Potpourri of Salt Commodity Info. Jakarta Selatan: AMP-Press.

Sandy, H.S, Gisma, A.F., \& Plato, M. (2017, in Indonesian). The Influence of Meteorological Aspects on Brackish Water Salt Production in Losarang Village, Indramayu Regency. In
SEMIRATA MIPA Universitas Sam Ratulangi, Manado.

Santosa, I. (2014, in Indonesian). Making Salt Using the Same Size Watertight Pond. Spektrum Ind. 12(1), 87-91.

Stan-Lotter, H., \& Fendrihan, S. (2011). Deep Biosphere of Salt Deposits. (p. 482). In: Reitner J., Thiel V. (eds) Encyclopedia of Geobiology. Encyclopedia of Earth Sciences Series. Springer, Dordrecht.

Wairiu, M., \& R. Lal. (2006). Tillage and Land Use Effects on Soil Microporosity in Ohio, USA and Kolombangara, Solomon Islands. Soil Tillage Res, 88(1), 80-84.

Yusman, D. (2019, in Indonesian). The Future of North Aceh's Salt Production Still Needs Government's Attention. http://rri.co.id/lhokseumawe/post/ berita/698732/ekonomi/masa_depan_produksi_ garam_aceh_utara_masih_perlu_perhatian_ pemerintah.html. Diakses tgl 28 November 2019.

Zuhud, A. (2014, in Indonesian). Analysis of the Effect of Evaporation Rate and Rainfall on Salt Production in Salt Land PT Garam (Persero) Sumenep. Skripsi. Institut Teknologi Bandung: Bandung. 